\title{
PERSEPSI MAHASISWA JURUSAN AKUNTANSI TERHADAP PERILAKU TIDAK ETIS AKUNTAN (STUDI KUANTITATIF PADA MAHASISWA POLITEKNIK NEGERI SAMARINDA)
}

\author{
Eko Adi Widyanto' ${ }^{1)}$, Rahmawati Fitriana ${ }^{2)}$, dan Al'Hasrin ${ }^{3)}$ \\ 1,2,3 Jurusan Akuntansi, Politeknik Negeri Samarinda \\ 1,2,3 J1. Dr. Cipto Mangunkusumo, Samarinda, 75131 \\ E-mail: eko@polnes.ac.id ${ }^{1)}$, asyura_krisnan@yahoo.com ${ }^{2)}$, alhasrin60@gmail.com ${ }^{3)}$
}

\begin{abstract}
ABSTRAK
Tujuan penelitian ini untuk mengetahui dan menganalisis pengaruh orientasi etis idealisme dan pengetahuan etika terhadap persepsi mahasiswa atas perilaku tidak etis akuntan. Penelitian dilakukan di 2 (dua) Program Studi pada Jurusan Akuntansi Politeknik Negeri Samarinda. Data yang digunakan adalah data primer berupa kuesioner atau angket. Dengan menggunakan rumus slovin, didapat jumlah responden sebanyak 176 orang mahasiswa dari total populasi 310 orang. Metode pengambilan data dilakukan dengan cara purposive sampling yakni pengambilan data berdasarkan kriteria atau tujuan tertentu. Teknik analisis data dilakukan dengan uji Instrumen yang terdiri dari uji validitas dan reliabilitas. Selanjutnya dilakukan pengujian asumsi klasik yang terdiri dari uji normalitas, uji heteroskedastisitas, uji multikolinieritas dan uji auto korelasi. Tahap terakhir dilakukan uji regresi berganda yang terdiri dari uji secara bersama-sama (simultan), uji secara parsial, serta dilengkapi dengan koefisien korelasi dan koefisien determinasi. Semua pengujian dilakukan dengan bantuan piranti lunak (Software) IBM SPSS v25. Hasil penelitian menunjukkan bahwa secara parsial orientasi etis idealisme tidak berpengaruh signifikan terhadap persepsi mahasiswa akuntansi atas perilaku tidak etis akuntan, sedangkan pengetahuan etika berpengaruh Negatif dan signifikan terhadap persepsi mahasiswa akuntansi atas perilaku tidak etis akuntan. secara simultan orientasi etis idealisme dan pengetahuan etika secara bersama berpengaruh terhadap persepsi mahasiswa akuntansi atas perilaku tidak etis akuntan
\end{abstract}

Kata Kunci : Orientasi Etis, Pengetahuan Etika, Perilaku Etis, Akuntan, Persepsi Mahasiswa.

\section{PENDAHULUAN}

Etika menjadi sebuah konsep dasar yang harus ditetapkan dalam bidang profesi. Prihanto (2018) menyatakan melalui etika, manusia dapat berperilaku terhadap apa yang dapat diterima maupun tidak diterima dalam organisasi dan masyarakat. Perilaku dan tindakan etis menjadi bagian penting dalam menjaga kepercayaan masyarakat terhadap bidang profesi. Guna menjaga agar setiap anggota profesi berperilaku dan bertindak etis maka dibuatlah peraturan berdasarkan prinsip moral pada umumnya yang disesuaikan dengan jenis profesi dalam bentuk kode etik profesi.

Prinsip etika dalam profesi akuntansi yang ditetapkan oleh Ikatan Akuntan Indonesia (IAI) yang berlaku sejak tahun 1998 diantaranya memuat 8 (delapan) prinsip antara lain: Tanggung Jawab Profesi, Kepentingan Publik, Integritas, Objektivitas, Kompetensi dan Kehati-hatian Profesional, Kerahasiaan, Perilaku Profesional dan Standar Teknis (Prihanto, 2018).

Big and Blocher (1998) dalam Prihanto (2018) mengemukakan bahwa terdapat tiga fungsi dari kode etik antara lain: melindungi profesi dari campur tangan pemerintah, mencegah terjadinya pertentangan internal dalam profesi, dan melindungi para praktisi dari kesalahan praktik suatu profesi. Akan tetapi, dalam praktiknya seorang akuntan sering dihadapkan dengan dilema etis dimana seorang akuntan harus mengambil keputusan tentang perilaku yang tepat dan sesuai dengan aturan kode etik profesi dalam melakukan pekerjaannya.

Adanya dilema etis yang dihadapi oleh para akuntan tidak jarang menimbulkan tindakan-tindakan yang melanggar kode etik profesi akuntan. Menurut Arens et al (2010) ada dua alasan mengapa seorang bertindak tidak etis yang pertama standar etika seseorang berbeda dengan standar etika yang berlaku di masyarakat umum dan yang kedua orang memilih untuk bertindak mementingkan diri sendiri. Salah satu skandal akuntansi yang melibatkan akuntan adalah yang dilakukan oleh British Telecom dan terindikasi pada tahun 2017. Fraud akuntansi yang dilakukan oleh British Telecom terjadi di salah satu lini usahanya di Italia. Fraud di British Telecom berdampak kepada akuntan publiknya yaitu Price Waterhouse Coopers (PwC) yang merupakan kantor akuntan publik ternama di dunia dan termasuk the bigfour.

Fraud akuntansi British Telecom gagal dideteksi oleh PwC dan justruberhasil dideteksi oleh pelapor pengaduan (whistleblower) yang dilanjutkan dengan akuntansi forensik oleh KPMG. Modus fraud akuntansi yang dilakukan British Telecom di Italia relatif sederhana yakni melakukan inflasi (peningkatan) atas laba perusahaan selama beberapa tahun menggunakan 
cara yang tidak wajar melalu kerja sama koruptif dengan klien-klien perusahaan dan jasa keuangan.

Di Indonesia sendiri, pelanggaran kode etik kerap kali terjadi. Seperti yang melibatkan Kantor Akuntan Publik mitra Ernst \& Young's (EY) di Indonesia yakni KAP Purwantono, Suherman \& Surja. Kasus tersebut berawal pada tahun 2012 ketika Kantor Akuntan Publik mitra EY di AS melakukan kajian atas hasil audit kantor akuntan di Indonesia. Mereka menemukan bahwa hasil audit atas perusahaan telekomunikasi yang dilakukan afiliasi EY di Indonesia tidak didukung dengan data yang akurat, yakni dalam hal persewaan lebih dari 4 ribu unit menara seluler, namun afiliasi EY di Indonesia merilis laporan hasil audit dengan status wajar tanpa pengecualian. Akibatnya KAP EY dikenakan denda sebesar US\$ 1 juta oleh Badan Pengawas Perusahaan Akuntan Publik Amerika Serikat (Public Company Accounting Oversight Board/PCAOB). Beberapa skandal akuntansi yang terjadi baik di luar maupun di dalam negeri merusak citra baik dari profesi akuntan, dan secara tidak langsung akan berpengaruh terhadap opini dan persepsi masyarakat, dimana kelompok masyarakat tersebut diantaranya adalah mahasiswa.

Mahasiswa jurusan akuntansi umumnya dibekali dengan pengetahuan mengenai etika dan perilaku di suatu organisasi dalam bentuk mata kuliah etika bisnis dan profesi. Mahasiswa akuntansi juga mendapatkan pengetahuan tentang pemeriksaan laporan keuangan dalam bentuk mata kuliah audit. Ini memberikan mereka pemahaman mengenai sikap etis dan etika dalam berorganisasi, independensi, integritas dan objektifitas dalam bekerja. Salah satu bidang pekerjaan yang tersedia untuk mereka nantinya adalah profesi auditor dan akuntan, baik akuntan perusahaan maupun akuntan publik. Profesi ini adalah salah satu bahan pertimbangan bahkan menjadi profesi favorit bagi mahasiswa jurusan akuntansi dalam memilih karier sebagai seorang auditor atau akuntan dimasa yang akan datang.

Banyaknya kasus kecurangan yang terjadi terkait pelanggaran etika dan integritas dimasa lalu seperti yang telah di deskripsikan diatas menjadi salah satu faktor yang mempengaruhi persepsi para mahasiswa akuntansi terhadap perilaku tidak etis akuntan yaitu orientasi etis dan pengetahuan etika.

Berdasarkan beberapa penelitian yang telah dilakukan sebelumnya, orientasi etis idealisme berpengaruh terhadap persepsi mahasiswa akuntansi atas perilaku tidak etis akuntan. Pernyataan tersebut didukung dengan penelitian Mardawati (2014) bahwa orientasi etis idealisme berpengaruh negatif terhadap persepsi mahasiswa akuntansi atas perilaku tidak etis akuntan, hasil tersebut sesuai dengan penelitian Damayanthi (2016) dan Sumiyantini (2017). Sedangkan pada penelitian Diwi (2015) orientasi etis berpengaruh positif terhadap persepsi mahasiswa jurusan akuntansi atas perilaku tidak etis akuntan. Hasil berbeda ditemukan Kholifah (2018) dan Yuliani (2019) di mana orientasi etis idealisme tidak berpengaruh signifikan terhadap persepsi mahasiswa akuntansi atas perilaku tidak etis akuntan. Pengetahuan etika juga berpengaruh terhadap persepsi mahasiswa atas perilaku tidak etis akuntan. Pernyataan tersebut sesuai dengan penelitian Mardawati (2014) yang menunjukkan bahwa pengetahuan etika berpengaruh negatif kepada persepsi mahasiswa terhadap perilaku tidak etis akuntan. Hasil tersebut juga sesuai dengan penelitian Damayanthi (2016) dan Sumiyantini (2017) bahwa tingkat pengetahuan memiliki pengaruh negatif terhadap perilaku tidak etis akuntan.

\section{RUANG LINGKUP}

Berdasarkan gambaran yang telah dipaparkan diatas, terdapat kecenderungan dari beberapa mahasiswa yang melihat bahwa besarnya potensi pelanggaran hukum yang terjadi, diakibatkan karena rendahnya etika akuntan dan kode etik yang dimiliki. Hal ini tentu saja bertentangan dengan pemahaman mereka saat ini saat mendapatkan pembelajaran mengenai etika dan audit.

Pertentangan ini dikhawatirkan akan memicu pemahaman yang berbeda dalam meyikapi suatu kasus atau peristiwa. Dampaknya akan membuat mereka bias dalam menilai batasan boleh atau tidak boleh dalam berprilaku. Banyaknya perbedaan persepsi dalam menilai kasus dan peristiwa terhadap etika ini menjadikannya sesuatu yang menarik untuk diteliti.

Penelitian ini dilakukan di Jurusan Akuntansi Politeknik Negeri Samarinda. Responden pada penelitian ini adalah mahasiswa yang telah mendapatkan mata kuliah Etika Bisnis dan Profesi, Audit 1, Audit 2, dan serta Praktik Audit. Pengukuran yang digunakan adalah variabel orientasi etis dan pengetahuan etika.

\subsection{Hipotesis Penelitian}

Berdasarkan paparan diatas, maka dapat dirumuskan hipotesis penelitian sebagai berikut "Orientasi etis dan pengetahuan etika, baik secara simultan maupun parsial berpengaruh signifikan terhadap persepsi mahasiswa akuntansi atas perilaku tidak etis akuntan".।

\section{BAHAN DAN METODE}

Berikut disajikan kajian teori dan metodologi yang berkaitan dengan penelitian ini

\subsection{Desain Penelitian}

Penelitian ini merupakan penelitian empiris dengan menggunakan metode pendekatan kuantitatif. Sugiyono (2017) menyatakan bahwa metode penelitian kuantitatif dapat diartikan sebagai metode penelitian yang berlandaskan pada filsafat positivisme, digunakan untuk meneliti pada populasi atau sampel tertentu, pengumpulan data menggunakan instrumen penelitian, analisis data bersifat statistik, dengan tujuan untuk menguji hipotesis yang telah ditetapkan, dimana dalam konteks penelitian ini hipotesis yang diajukan adalah untuk menggambarkan bagaimana persepsi mahasiswa akuntansi atas perilaku tidak etis akuntan. 


\subsection{Populasi dan Sampel}

Jenis data yang digunakan dalam penelitian ini adalah data kuantitatif. Data yang digunakan merupakan data primer yang diperoleh melalui cara menyebarkan kuesioner secara online menggunakan aplikasi google form. Populasi pada penelitian ini adalah mahasiswa program studi D3 Akuntansi angkatan 2016, mahasiswa program studi S1 Terapan Akuntansi Manajerial angkatan 2016 dan angkatan 2015 jurusan Akuntansi Politeknik Negeri Samarinda sebanyak 310 responden.

Teknik pengambilan sampel menggunakan metode Sampling Purposive dengan kriteria mahasiswa telah menempuh mata kuliah audit 1, audit 2, Praktikum Audit dan mata kuliah Etika Bisnis dan Profesi. Penentuan jumlah sampel dihitung dengan menggunakan rumus Slovin dan diperoleh hasil sampel sebanyak 176 responden.

\subsection{Instrumen Penelitian}

Pengukuran penelitian ini dilakukan dengan skala Likert yang dimodifikasi dengan empat alternatif pilihan jawaban. Responden diminta untuk mengisi jawaban atas pernyataan dalam bentuk verbal dengan kategori yang telah ditentukan, dan masing-masing jawaban tersebut diberikan skor sesuai krirteria jawaban responden.

Pada kuesioner mengenai persepsi mahasiswa akuntansi atas perilaku tidak etis akuntan, penelitian ini mengadaptasi kuesioner yang sebelumnya telah digunakan oleh Mardawati (2014) yang dikembangkan oleh Hai Yap Toeh et al. Sedangkan untuk menilai orientasi etis seorang individu, penelitian ini mengadaptasi Ethics Position Questionnaire (EPQ) yang dikembangkan oleh Forsyth (1980). Pada kuesioner pengetahuan etika profesi akuntan peneliti mengadaptasi kuesioner yang dikembangkan oleh Mardawati (2014).

Adapaun dari hasil penelitian sebelumnya, dapat dirimuskan model penelitian dapat dilihat pada gambar 1 .

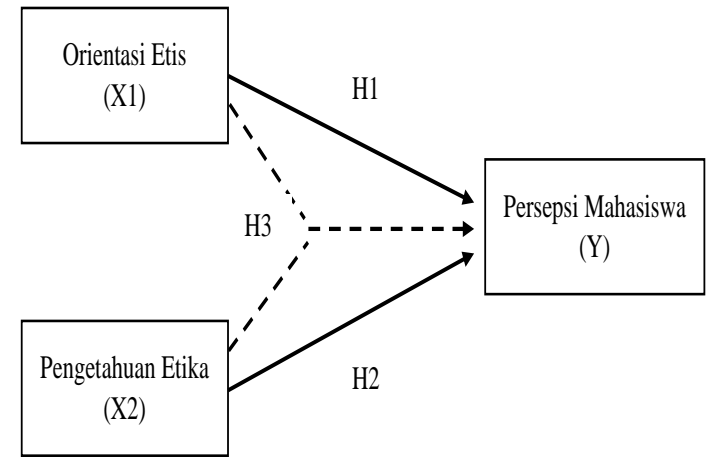

Gambar 1. Model Penelitian

\section{PEMBahasan}

Data penelitian dikumpulkan dengan menyebar kuesioner secara online menggunakan aplikasi google form kepada para Mahasiswa Akuntansi di Politeknik Negeri Samarinda. Penyebaran kuesioner dilakukan sejak tanggal 21 Maret 2019 hingga tanggal 21 April 2019 dengan menggunakan sistem one shot.
Kuesioner yang disebar diberi batas kuota sebanyak 250 kuesioner. Dari batas kuota yang disebar sebanyak 210 kuesioner kembali, namun terdapat 40 kuesioner yang tidak memenuhi persyaratan sehingga tidak dapat dilakukan analisis lebih lanjut. Karena jumlah kuesioner yang layak adalah 210, maka diambil kuesioner yang digunakan sebagai bahan analisis telah lengkap, yakni 176 buah.

\subsection{Uji Kualitas Data}

Adapun pengujian kualitas data dibagi menjadi 2 yaitu, uji validasi dan uji reliabilitas

\section{Uji Validitas}

Uji Validitas digunakan untuk mengukur valid atau tidaknya suatu instrumen yang digunakan untuk memperoleh data dalam suatu penelitian. Menurut Sugiyono (2017) valid berarti instrumen tersebut dapat digunakan untuk mengukur apa yang seharusnya diukur.

Tabel 1. Uji Validitas

\begin{tabular}{|c|c|c|c|}
\hline $\begin{array}{c}\text { Item } \\
\text { Pernyataan }\end{array}$ & $\begin{array}{c}\text { Nilai } \\
\text { Pearson }\end{array}$ & r Tabel & Keputusan \\
\hline Y.P1 & 0,550 & 0,1480 & Valid \\
\hline Y.P2 & 0,521 & 0,1480 & Valid \\
\hline Y.P3 & 0,727 & 0,1480 & Valid \\
\hline Y.P4 & 0,729 & 0,1480 & Valid \\
\hline Y.P5 & 0,767 & 0,1480 & Valid \\
\hline X1.P1 & 0,518 & 0,1480 & Valid \\
\hline X1.P2 & 0,587 & 0,1480 & Valid \\
\hline X1.P3 & 0,644 & 0,1480 & Valid \\
\hline X1.P4 & 0,638 & 0,1480 & Valid \\
\hline X1.P5 & 0,628 & 0,1480 & Valid \\
\hline X1.P6 & 0,662 & 0,1480 & Valid \\
\hline X1.P7 & 0,578 & 0,1480 & Valid \\
\hline X1.P8 & 0,652 & 0,1480 & Valid \\
\hline X1.P9 & 0,643 & 0,1480 & Valid \\
\hline X1.P10 & 0,604 & 0,1480 & Valid \\
\hline X2.P1 & 0,526 & 0,1480 & Valid \\
\hline X2.P2 & 0,767 & 0,1480 & Valid \\
\hline X2.P3 & 0,646 & 0,1480 & Valid \\
\hline X2.P4 & 0,669 & 0,1480 & Valid \\
\hline X2.P5 & 0,634 & 0,1480 & Valid \\
\hline X2.P6 & 0,607 & 0,1480 & Valid \\
\hline X2.P7 & 0,717 & 0,1480 & Valid \\
\hline X2.P8 & 0,747 & 0,1480 & Valid \\
\hline X2.P9 & 0,549 & 0,1480 & Valid \\
\hline X2.P10 & 0,783 & 0,1480 & Valid \\
\hline & & & \\
\hline
\end{tabular}

Hasil uji validitas pada Tabel 1 menunjukkan bahwa seluruh item pernyataan dinyatakan valid, hal tersebut berdasarkan nilai pearson correlation atau nilai $\mathrm{r}_{\text {hitung }}$ yang lebih besar dari pada nilai $\mathrm{r}_{\text {tabel }}(0,1480)$.

\section{Hasil Uji Reliabilitas}

Uji Reliabilitas digunakan untuk menunjukkan keandalan suatu instrumen yang digunakan untuk mendapatkan data atau informasi dalam sebuah penelitian yang sudah dilakukan. Sugiyono (2017) menyatakan bahwa reliabel adalah instrumen yang bila digunakan beberapa kali 
untuk mengukur obyek yang sama, akan menghasilkan data yang sama.

Tabel 2. Uji Reliabilitas

\begin{tabular}{|l|c|c|c|}
\hline \multicolumn{1}{|c|}{ Variabel } & $\mathrm{Y}$ & $\mathrm{X} 1$ & $\mathrm{X} 2$ \\
\hline Cronbach's Alpha & 0,681 & 0,812 & 0,861 \\
\hline Item Pertanyaan & 5 & 10 & 10 \\
\hline Keputusan & Reliabel & Reliabel & Reliabel \\
\hline
\end{tabular}

Hasil uji reliabilitas pada Tabel 2 menunjukkan seluruh instrumen yang gunakan untuk mengukur masing-masing variabel memiliki nilai Cronbach's Alpha di atas 0,60.

\subsection{Uji Asumsi Klasik}

Adapun pengujian asumsi klasik dibagi menjadi 4 yaitu, uji normalitas, multikolinearitas, heteroskedastisitas, dan autokorelasi

\section{Uji Normalitas}

Uji normalitas bertujuan untuk menguji apakah model regresi yang digunakan memiliki variabel residual yang terdistribusi secara normal atau tidak. Dalam penelitian ini, uji normalitas yang digunakan adalah KolgomorovSmirnov.

Tabel 3 Hasil Uji Normalitas One-Sample KolmogorovSmirnov Test

\begin{tabular}{|c|c|c|}
\hline & & zed Residual \\
\hline $\mathrm{N}$ & & 176 \\
\hline Normal & Mean & ,0427554 \\
\hline Parameters ${ }^{\mathrm{a}, \mathrm{b}}$ & Std. Deviation & 1,92766870 \\
\hline Most Extreme & Absolute & 055 \\
\hline Differences & Positive & 055 \\
\hline & Negative &,- 038 \\
\hline Test Statistic & & 055 \\
\hline Asymp. Sig. (2 & ed) & $200^{\mathrm{c}, \mathrm{d}}$ \\
\hline
\end{tabular}

Tabel 3 Hasil uji normalitas One-Sample KolmogorovSmirnov Test diatas diperoleh nilai $\mathrm{D}_{\text {hitung }}$ (Absolute) sebesar 0,055 lebih kecil dari nilai $\mathrm{D}_{\text {tabel }}$ (jumlah $\mathrm{N}=176$ ) yaitu sebesar 0,102 dan nilai Asymp. Sig. (2-tailed) sebesar 0,200 lebih besar dari 5\% (0,05). Berdasarkan hasil pengujian tersebut maka dapat disimpulkan bahwa data yang diolah dalam penelitian ini telah terdistribusi dengan normal.

\section{Hasil Uji Multikolinearitas}

Uji Multikolinearitas bertujuan untuk menguji adanya korelasi antara variabel bebas. Jika antara variabel bebas tersebut berkorelasi sangat kuat, maka secara logika persamaan regresinya cukup diwakili oleh salah satu variabel saja (Yudiaatmaja, 2013).

Tabel 4 Hasil Uji Multikolinearitas Coefficients ${ }^{\mathrm{a}}$

\begin{tabular}{|l|c|c|}
\hline \multirow{2}{*}{ Model } & \multicolumn{2}{|c|}{ Collinearity Statistics } \\
\cline { 2 - 3 } & Tolerance & VIF \\
\hline Orientasi Etis &, 645 & 1,549 \\
Pengetahuan Etika &, 645 & 1,549 \\
\hline
\end{tabular}

Pada tabel 4 di atas dapat diketahui bahwa nilai tolerance untuk masing-masing variabel independen lebih besar dari $10 \%(0,1)$ dan nilai VIP untuk masing-masing variabel lebih kecil dari 10. Sehingga dapat disimpulkan bahwa tidak terjadi multikolinearitas.

\section{Hasil Uji Heteroskedastisitas}

Uji hesteroskedastisitas digunakan untuk melihat apakah terdapat ketidaksamaan varian dari residual pengamatan yang satu ke pengamatan lainnya. Apabila timbul ketidaksamaan varian, maka terdapat masalah heteroskedastisitas. Dalam penelitian ini untuk menguji apakah terdapat gejala heteroskedastisitas digunakan uji Glejser. Pada prinsipnya uji Glejser menghitung nilai F dan membandingkannya dengan $F_{\text {tabel }}$ untuk mengetahui apakah ada pengaruh yang signifikan variabel bebas terhadap harga mutlak galatnya $|e|$ (Yudiaatmaja, 2013).

Tabel 5. Hasil Uji Heteroskedastisitas

\begin{tabular}{|l|c|c|c|c|}
\hline Model & df & $\begin{array}{c}\text { Mean } \\
\text { Square }\end{array}$ & F & Sig. \\
\hline Regression & 2 & 2,254 & 1,588 &, $207^{\mathrm{b}}$ \\
Residual & 173 & 1,420 & & \\
Total & 175 & & & \\
\hline
\end{tabular}

Pada tabel 5 di atas menunjukkan nilai $\mathrm{F}$ hitung sebesar 1,588 lebih kecil dari nilai $\mathrm{F}$ tabel yaitu sebesar 3,05. Hal tersebut memiliki arti bahwa variabel bebas tidak signifikan dalam menjelaskan variasi yang terjadi pada variabel dependen (dalam hal ini harga mutlak galatnya).

Dapat disimpulkan bahwa tidak satupun variabel independen yang signifikan secara statistik mempengaruhi nilai absolut variabel dependen atau dapat dikatakan bahwa tidak terdapat gejala heteroskedastisitas dalam model regresi yang digunakan dalam penelitian ini.

\section{Hasil Uji Autokorelasi}

Uji Autokorelasi dimaksudkan untuk menguji apakah pada model regresi linier ada korelasi antara variabel pengganggu pada periode t ke periode t-1 (satu periode sebelumnya). Untuk menguji ada tidaknya gejala ini dalam model analisis regresi yang digunakan, maka dilakukan pengujian dengan metode Durbin-Watson (D-W) dari data yang ada (Yudiaatmaja, 2013).

\section{Tabel 6 Hasil Uji Autokorelasi}

\begin{tabular}{|r|r|r|r|r|}
\hline Model & R & R Square & $\begin{array}{c}\text { Adjusted R } \\
\text { Square }\end{array}$ & Durbin-Watson \\
\hline, $255^{\mathrm{a}}$ &, 065 &, 054 & 1,931 \\
\hline
\end{tabular}

Pada tabel 6 di atas dapat diketahui nilai dW (DurbinWatson) sebesar 1,931. Sementara itu nilai dU sebesar 1,776 dan 4-dU sebesar 2,224, jadi nilai d berada di antara dU dan 4-dU yaitu $1,776<1,931<2,224$. Berdasarkan hasil pengujian tersebut maka dapat disimpulkan bahwa tidak terjadi autokorelasi pada model regresi yang digunakan dalam penelitian ini. 


\subsection{Uji Hipotesis}

Adapun pengujian hipotesis dibagi menjadi 3 yaitu, uji analisis korelasi dan determinasi, uji parsial, dan uji simultan.

\section{Koefisien Korelasi (R) dan Determinasi $\left(\mathrm{R}^{2}\right)$}

Uji analisis korelasi ganda digunakan untuk menguji korelasi linear antara satu variabel dependen (Y) dengan beberapa (dua atau lebih) variabel independen (X) (Widiyanto, 2013).

Tabel 7. Hasil Uji Koefisien Korelasi dan Determinasi

\begin{tabular}{|c|c|c|c|}
\hline \multicolumn{4}{|c|}{ Model Summary } \\
\hline $\mathrm{R}$ & $\begin{array}{c}\mathrm{R} \\
\text { Square }\end{array}$ & $\begin{array}{c}\text { Adjusted } \\
\mathrm{R} \text { Square }\end{array}$ & $\begin{array}{c}\text { Std. Error of } \\
\text { the Estimate }\end{array}$ \\
\hline, $357^{\mathrm{a}}$ & 0,128 & 0,118 & 1,938 \\
\hline Predictors: (Constant), X2.PE, X1.OE \\
\hline
\end{tabular}

Pada tabel 10 diatas besarnya nilai $(\mathrm{R})$ adalah 0,357 atau $35,7 \%$. Hal tersebut memiliki arti bahwa antara variabel orientasi etis dan pengetahuan etika memiliki hubungan yang kurang kuat terhadap variabel persepsi mahasiswa akuntansi atas perilaku tidak etis akuntan.

Uji Koefisien determinasi dilakukan untuk menghitung besarnya kontribusi variabel orientasi etis dan pengetahuan etika terhadap persepsi mahasiswa akuntansi atas perilaku tidak etis akuntan. Koefisien determinasi adalah besarnya kontribusi variabel bebas terhadap variabel terikat (Widiyanto, 2013).

Berdasarkan pada tabel 11 menunjukkan bahwa besarnya nilai Adjusted $R^{2}$ adalah 0,118 atau sebesar $11,8 \%$. Hal ini berarti variabel orientasi etis idealisme dan pengetahuan etika mampu menjelaskan variabel persepsi mahasiswa akuntansi atas perilaku tidak etis akuntan sebesar $11,8 \%$, sisanya sebesar $88,2 \%$ dijelaskan oleh faktor-faktor lainnya yang tidak diuji atau digunakan dalam penelitian ini.

Selanjutnya akan dilakukan pengujian regresi linier berganda. Regresi Linier Berganda digunakan untuk meramalkan bagaimana keadaan (naik turunnya) variabel dependen (kriterium), bilai dua atau lebih variabel independen sebagai faktor prediktor dimanipulasi (dinaikturunkan nilainya) (Sugiyono, 2017).

Tabel 8. Hasil Uji Regresi Linier Berganda

\begin{tabular}{|c|c|c|}
\hline \multirow{2}{*}{ Model } & \multicolumn{2}{|c|}{ Unstandardized Coefficients } \\
\hline & $\mathrm{B}$ & Std. Error \\
\hline (Constant) & 14,562 & 1,493 \\
\hline Orientasi Etis & 0,033 & 0,053 \\
\hline Pengetahuan Etika & $-0,181$ & 0,041 \\
\hline
\end{tabular}

Berdasarkan hasil perhitungan regresi pada tabel 7 di atas, maka dapat diperoleh persamaan regresi linier berganda dalam sebagai berikut (1).

$$
\mathrm{Y}=14,562+0,033 \mathrm{X}_{1}-0,181 \mathrm{X}_{2}+e
$$

Dari persamaan regresi (1) diketahui bahwa konstanta regresi mempunyai nilai 14,562 yang berarti bahwa jika variabel orientasi etis dan pengetahuan etika tidak ada maka nilai dari variabel persepsi mahasiswa akuntansi atas perilaku tidak etis akuntan mempunyai nilai konstan sebesar 14,562. Berdasarkan hasil persamaan regresi linier berganda tersebut dapat disimpulkan:

1) Koefisien variabel orientasi etis idealisme memengaruhi persepsi mahasiswa akuntansi atas perilaku tidak etis akuntan sebesar 0,033. Berarti apabila nilai orientasi etis idealisme meningkat sebesar 1 satuan maka nilai persepsi mahasiswa akuntansi terhadap perilaku tidak etis akuntan akan ikut meningkat sebesar 0,033 satuan.

2) Koefisien variabel pengetahuan etika memengaruhi persepsi mahasiswa akuntansi atas perilaku tidak etis akuntan sebesar -0,181. Berarti apabila nilai pengetahuan etika meningkat sebesar 1 satuan maka nilai persepsi mahasiswa akuntansi atas perilaku tidak etis akuntan akan turun sebesar -0,181 satuan.

\section{Hasil Uji t (Uji Parsial)}

Uji $\mathrm{t}$ dilakukan dengan ketentuan apabila hasil $\mathrm{t}_{\text {hitung }}>\mathrm{t}$ tabel dengan taraf signifikan sebesar 5\%, maka variabel independen memiliki pengaruh yang signifikan terhadap variabel dependen dan apabila $\mathrm{t}_{\text {hitung }}<\mathrm{t}_{\text {tabel }}$ maka variabel tidak memiliki pengaruh yang signifikan (Widiyanto, 2013).

Tabel 9. Hasil Uji t (Uji Parsial)

\begin{tabular}{|c|l|c|c|}
\hline \multicolumn{2}{|c|}{ Model } & $\mathrm{T}$ & Sig. \\
\hline \multirow{3}{*}{1} & (Constant) & 9,753 & 0,000 \\
\cline { 2 - 4 } & Orientasi Etis & 0,617 & 0,538 \\
\cline { 2 - 4 } & Pengetahuan Etika & $-4,382$ & 0,000 \\
\hline
\end{tabular}

Berdasarkan pada tabel 8 di atas, pada variabel X1 diperoleh nilai $\mathrm{t}$ hitung sebesar 0,617. Nilai $\mathrm{t}$ hitung yang dihasilkan lebih kecil dari pada nilai $t$ tabel yaitu sebesar 1,974. Dengan demikian hipotesis 1 ditolak.

Pada variabel $\mathrm{X} 2$ diperoleh nilai $\mathrm{t}$ hitung sebesar 4,382. Nilai $\mathrm{t}$ hitung. Nilai $\mathrm{t}$ hitung yang dihasilkan lebih besar dari pada nilai $\mathrm{t}_{\text {tabel }}$ yaitu sebesar 1,974. Nilai koefisien regresi menunjukkan arah hubungan negatif sebesar $-0,181$. Dengan demikian hipotesis 2 diterima.

\section{Hasil Uji F (Simultan)}

Uji $\mathrm{F}$ dilakukan dengan ketentuan apabila nilai $\mathrm{F}_{\text {hitung }}>$ nilai $\mathrm{F}$ tabel dengan taraf signifikansi sebesar 5\%, maka terdapat pengaruh yang signifikan antara variabel independen terhadap variabel dependen. Sebaliknya apabila nilai $\mathrm{F}_{\text {hitung }}<$ nilai $\mathrm{F}_{\text {tabel }}$ maka tidak terdapat pengaruh yang signifikan antara variabel independen dengan variabel dependen (Widiyanto, 2013). 
Tabel 10 Hasil Uji F (Uji Simultan)

\begin{tabular}{|l|r|r|r|c|}
\hline Model & Df & $\begin{array}{c}\text { Mean } \\
\text { Square }\end{array}$ & F & Sig. \\
\hline Regression & 2 & 47,612 & 12,673 &, $000^{\mathrm{b}}$ \\
Residual & 173 & 3,757 & & \\
Total & 175 & & & \\
\hline
\end{tabular}

Pada tabel 9 diperoleh nilai $\mathrm{F}_{\text {hitung }}$ sebesar 12,673 yang lebih besar dari nilai $F$ tabel sebesar 3,05 dan nilai signifikansi sebesar 0,00 yang lebih kecil dari taraf signifikansi $5 \%$ atau 0,05 . Dengan demikian hipotesis 3 diterima.

\subsection{Interpretasi Hasil Analisis}

Terdapat 3 hipotesis dari hasil analisis, dijabarkan sebagai berikut:

\section{Pengaruh Orientasi Etis Idealisme terhadap Persepsi} Mahasiswa Akuntansi atas Perilaku Tidak Etis Akuntan

Hipotesis pertama menyatakan bahwa orientasi etis idealisme berpengaruh terhadap persepsi mahasiswa akuntansi atas perilaku tidak etis akuntan. Hasil analisis yang diperoleh menunjukkan tingkat signifikansi sebesar 0,538 lebih besar dari $0,05(5 \%)$ dan nilai $t$ hitung sebesar 0,617 lebih kecil dari pada nilai $t_{\text {tabel }}$ yaitu 1,974 sehingga orientasi etis tidak berpengaruh terhadap persepsi mahasiswa atas perilaku tidak etis akuntan yang menunjukkan $\mathrm{H} 1$ ditolak.

Tidak berpengaruhnya orientasi etis idealisme terhadap persepsi mahasiswa akuntansi atas perilaku tidak etis akuntan dapat terjadi akibat faktor eksternal dan keinginan pribadi dari dalam diri mahasiswa untuk mencapai tujuan yang sulit dicapai apabila menggunakan cara yang tidak melanggar etika. Sehingga mahasiswa cenderung mengabaikan aturan etika yang berlaku atau lebih memilih untuk melakukan tindakan yang tidak etis. Adanya kesempatan dan suatu hal yang bersifat memaksa juga menjadi salah satu penyebab mahasiswa cenderung melakukan tindakan tidak etis.

\section{Pengaruh Pengetahuan Etika terhadap Persepsi} Mahasiswa Akuntansi atas Perilaku Tidak Etis Akuntan

Hipotesis kedua menyatakan bahwa pengetahuan Etika berpengaruh terhadap persepsi mahasiswa akuntansi atas perilaku tidak etis akuntan. Hasil analisis yang diperoleh menunjukkan tingkat signifikansi sebesar 0,000 lebih kecil dari $0,05(5 \%)$ dan nilai $\mathrm{t}$ hitung menunjukkan hasil negatif sebesar 4,382 lebih besar dari pada nilai $t$ tabel yaitu 1,974 sehingga pengetahuan etika berpengaruh negatif terhadap persepsi mahasiswa atas perilaku tidak etis akuntan yang menunjukkan $\mathrm{H} 2$ diterima.

Mahasiswa yang memiliki pengetahuan yang luas mengenai prinsip etika profesi akuntan akan bersikap lebih bijaksana dan memberikan tanggapan berupa ketidaksetujuan mengenai skandal etis yang menimpa profesi akuntan berkaitan dengan penerapan prinsip etika profesi akuntan dibandingkan dengan mahasiswa yang memiliki pengetahuan lebih sedikit.

\section{Pengaruh Orientasi Etis Idealisme dan Pengetahuan} Etika Secara Bersama terhadap Persepsi Mahasiswa Jurusan Akuntansi atas Perilaku Tidak Etis Akuntan

Hipotesis ketiga menyatakan bahwa orientasi etis idealisme dan pengetahuan etika secara bersama berpengaruh terhadap persepsi mahasiswa akuntansi atas perilaku tidak etis akuntan. Hasil analisis yang diperoleh menunjukkan tingkat signifikansi sebesar 0,000 lebih kecil dari $0,05(5 \%)$ dan nilai $F$ hitung sebesar 12,673 lebih besar dari pada nilai $F$ tabel yaitu 3,05 sehingga orientasi etis idealisme dan pengetahuan etika secara bersama (simultan) berpengaruh terhadap persepsi mahasiswa akuntansi atas perilaku tidak etis akuntan. Berdasarkan hasil analisis dan pengujian menunjukkan bahwa $\mathrm{H} 3$ diterima.

\section{KESIMPULAN}

Orientasi etis dan pengetahuan etika secara bersamasama (simultan) berpengaruh signifikan terhadap persepsi mahasiswa akuntansi atas perilaku tidak etis akuntan. Secara parsial, Orientasi etis idealisme tidak berpengaruh signifikan terhadap persepsi mahasiswa akuntansi atas perilaku tidak etis akuntan, sedangkan Pengetahuan etika berpengaruh negatif dan signifikan”.

\section{SARAN}

Tidak berpengaruhnya orientasi etis idealisme terhadap persepsi mahasiswa atas perilaku tidak etis akuntan pada penelitian ini membuka peluang untuk dilakukan riset berikutnya. Di masa mendatang, diharapkan agar mata kuliah etika profesi dapat lebih ditekankan dengan menekankan pada contoh kasus kecurangan yang terjadi berkaitan dengan kasus audit. Ini penting agar mahasiswa memiliki karakter dan sikap idealisme yang sesuai dengan etika profesi yang berlaku.

\section{DAFTAR PUSTAKA}

Arens, A. A., Elder, R. J., \& Beasley, M. S. 2001. Auditing and Anssurance Service-An Integrrated Appproach $(9$ ed.). (T. Dejacarta, Penerj.) New Jersey: Pearson Education, Inc.

Arens, A. A., Elder, R. J., \& Beasley, M. S. 2008. Auditing and Assurance Service-An Integrrated Appproach (12 ed.). (W. Hardani , S. Saat, Penyunt., \& H. Wibowo, Penerj.) Jakarta: Erlangga.

Arijanto, A. 2011. Etika Bisnis bagi Pelaku Bisnis Cara Cerdas dalam Memahami Konsep dan Faktor-faktor Etika Bisnis dengan Beberapa Contoh. Jakarta: Rajawali Pers.

Bertens, K. 2007. ETIKA. Jakarta: Gramedia Pustaka Utama.

Damayanthi, P. A., \& Juliarsa, G. 2016. Pengaruh Idealisme, Relativisme, Pengetahuan, Gender Dan Umur Pada Perilaku Tidak Etis Akuntan. E-Jurnal Akuntansi Universitas Udayana, Vol.15.1., 1-16. 
Dewi, H. N. 2010. Persepsi Mahasiswa Akuntansi Atas Perilaku Tidak Etis Akuntan (Studi Pada Universitas Kristen Satya Wacana). Skripsi. Fakultas Ekonomi Universitas Diponegoro.

Diwi, D. 2015. Pengaruh Orientasi Etis dan Gender terhadap Persepsi Mahasiswa Mengenai Perilaku Tidak Etis Akuntan (Studi Pada Mahasiswa S1 Jurusan Akuntansi Universitas Negeri Yogyakarta). Skripsi. Program Studi Akuntansi Jurusan Pendidikan Akuntansi Fakultas Ekonomi: Universitas Negeri Yogyakarta.

Forsyth, D. R. 1980. A Taxonomy of Ethical Ideologi. Journal of Personality and Social Psychology, 39, 175-184.

Forsyth, D. R. 1992. Judging the Morality of Business Practices: The Influence of Personal Moral Philosophies. Journal of Business Ethics, 461-470.

Forsyth, D. R., \& Nye, J. L. 1990. Personal Moral Philosophies and Moral Choice. Journal of Research in Personality, 398-414.

Hery. 2015. Pengantar Akuntansi. Jakarta: Grasindo.

Ikatan Akuntan Indonesia. 2016. Kode Etik Profesional.

Institut Akuntan Publik Indonesia. (2008). Kode Etik Profesi Akuntan Publik.

Ismail. 2014. Akuntansi Bank Teori dan Aplikasi dalam Rupiah. Jakarta: Kencana.

Keraf, A. S. 2005. Etika Bisnis: Tuntutan dan Relevansinya. Yogyakarta: Kanisius.

Kholifah, I. N. 2018. Pengaruh Idealisme, Relativisme, dan Pengetahuan Etika Terhadap Persepsi Mahasiswa Akuntansi atas Perilaku Tidak Etis Akuntan. Jurnal Kajian Ilmiah Akuntansi Fakultas Ekonomi UNTAN, Vol 7, No 2.

Ling, J., \& Catling, J. 2012. Psychology Express: Cognitive Psychology. (R. Rahmat, A. Maulana, Penyunt., \& N. F. Widuri, Penerj.) Ciracas, Jakarta, Indonesia: Erlangga.

Lubis, A. I. 2010. Akuntansi Keperilakuan (4 ed.). Jakarta: Salemba Empat.

Mardawati, R. 2014. Pengaruh Orientasi Etis, Gender, Dan Pengetahuan Etika Terhadap Persepsi Mahasiswa Akuntansi Atas Perilaku Tidak Etis Akuntan (Studi pada Mahasiswa Akuntansi Universitas Negeri Yogyakarta). Skripsi. Fakultas Ekonomi: Universitas Negeri Yogyakarta.

Prihanto, H. 2018. Etika Bisnis \& Profesi: Sebuah Pencarian. Depok: Rajawali Pers.

Sekaran, U. 1992. Research Methods for Business. Shoutern Illinois University at Carbondale.

Siregar, S. 2017. Statistik Parametrik untuk Penelitian Kuantitatif Dilengkapi dengan Perhitungan Manual dan Aplikasi Versi 17 (5 ed.). (F. Hutari, Penyunt.) Jakarta: Bumi Aksara.

Sugiyono. 2017. Metode Penelitian Bisnis Pendekatan Kuantitatif, Kualitatif, Kombinasi, dan R\&D (3 ed.). Bandung: Alfabeta.

Sugiyono. 2018. Metode Penelitian Kuantitatif . Bandung: Alfabeta.
Sumiyantini, N. K., Sinarwati, N. K., \& Atmadja, A. T 2017. Persepsi Mahasiswa Jurusan Akuntansi Mengenai Idealisme, Relativisme Dan Tingkat Pengetahuan Pada Perilaku Tidak Etis Akuntan (Studi Mahasiswa Jurusan Akuntansi Universitas Ganesha). e-journal S1 Ak Universitas Pendidikan Ganesha, Vol. 7.

Supriyono, R. 2018. Akuntansi Keperilakuan. (Mash, Penyunt.) Yogyakarta: Gadjah Mada University Press.

Tandiontong, M. 2016. Kualitas Audit dan Pengukurannya. Bandung: Alfabeta.

Undang-undang Republik Indonesia Nomor 34 Tahun 1954 tentang Pemakaian Gelar Akuntan. (t.thn.).

Widiyanto, M. A. 2013. Statistika Terapan Konsep \& Aplikasi SPSS/LISREL dalam Penelitian Pendidikan, Psikologi \& Ilmu Sosial Lainnya. Jakarta: PT Elex Media Komputindo.

Yosephus, L. S. 2010. Eika Bisnis: Pendekeatan Filsafat Moral Terhadap Perilaku Pebisnis Kontemporer. Jakarta: Yayasan Pustaka Obor Indonesia.

Yudiaatmaja, F. 2013. Analisis Regresi Dengan Menggunakan Aplikasi Komputer Statistik SPSS. Jakarta: Gramedia Pustaka Utama.

Yuliani, K. S. 2019. Pengaruh Orientasi Etika, Tingkat Pengetahuan dan Gender terhadap Persepsi Mahasiswa Mengenai Perilaku Tidak Etis Akuntan. Jurnal Sains, Akuntansi dan Manajemen. Universitas Mahasaraswati Denpasar, Vol. 1, No. 1.

\section{UCAPAN TERIMA KASIH}

Terima Kasih kepada Politeknik Negeri Samarinda yang telah memberikan kesempatan kepada peneliti untuk mempublikaikan karya ini di Jurnal SEBATIK 